This is an Accepted Manuscript of the article Villamayor-Tomas, S., \& García-López, G. (2017). The influence of community-based resource management institutions on adaptation capacity: A large-n study of farmer responses to climate and global market disturbances. Global Environmental Change, 47, 153-166., available online at: https://doi.org/10.1016/j.gloenvcha.2017.10.002. @2018. This manuscript version is made available under the CC-BY-NC-ND 4.0 license.

\title{
The influence of community-based resource management institutions on adaptive capacity: A large-n study of farmer responses to climate and global market disturbances
}

\author{
Sergio Villamayor-Tomas ${ }^{\mathrm{a}, \mathrm{c}}$, Gustavo García-López ${ }^{\mathrm{b}, \mathrm{c}}$ \\ ${ }^{a}$ Institut de Ciència i Tecnologia Ambientals (ICTA), Universitat Autonoma de Barcelona, Building \\ Z Campus UAB 08193 Bellaterra (Cerdanyola), Barcelona, Spain \\ ${ }^{\mathrm{b}}$ Escuela Graduada de Planificación, Universidad de Puerto Rico, San Juan, 00925, Puerto Rico \\ ${ }^{c}$ Ostrom Workshop in Political Theory and Policy Analysis, Indiana University, 513 N. Park Ave., \\ 47408, Bloomington, IN, United States
}

\begin{abstract}
:
An underlying understanding among adaptation and community-based natural resource management (CBNRM) scholars is the existence of important feedbacks between local resource management institutions and individual adaptive capacity. The relationship between CBNRM and individual adaptive capacity is of global concern given the ubiquity of CBNRM worldwide, the patent impacts of global changes at local levels, and the recent calls for the integration of climate and rural development policies. So far, however, there have not been formal, large-n studies of that relationship. This study aims to fill that gap by testing whether the performance of community-based water management institutions and communal land regimes have an impact on the effectiveness of farmers' adaptation responses to climatic and global market disturbances. For this purpose, the study relies on a unique dataset of individual and collective features obtained from water user associations (WUAs) and ejidos in Mexico. According to the regression results, well-functioning community-based water management institutions have a positive and significant impact on individual farmers' self-reported response effectiveness. The impact of communal land property is also significant but negative. These effects, which hold only in the context of climate disturbances but not market disturbances, can be explained by looking at the support given by the associations to farmers, and issues of communal land marginalization, respectively. Policies that strengthen the autonomy and capacity for cooperation of WUAs and ameliorate structural deficits in communal land regimes shall not only guarantee a long-advocated path for rural development but also help farmers deal with some of the climatic uncertainties that increasingly threaten agriculture.
\end{abstract}




\section{Introduction}

Agriculture worldwide is increasingly exposed to a wide range of climatic and socio-economic pressures, including droughts, floods and plagues, input and crop price volatility and competition over land and water resources (Feola et al., 2015). This has raised concerns about meeting human demands for water and food (Godfray et al., 2010), and given rise to a substantial scholarship on farmer adaptation. A good number of adaptation scholars have focused on the factors that explain the willingness and capacity of individual farmers' to respond to climate change and variability (Feola et al., 2015, Eakin et al., 2006, Pradhan et al., 2015, Eakin et al., 2014). Community-based natural resource management (CBNRM) scholars, on the other hand, have focused on understanding the capacity of local resource-dependent communities to manage their shared resources cooperatively, and on how socio-ecological disturbances impact that capacity and shape collective adaptations (Anderies et al., 2004, Fleischman et al., 2010, Cox, 2014, Villamayor-Tomas, 2014). An underlying understanding among authors from both traditions is the existence of important feedbacks between CBNRM and individual adaptive capacity (Adger, 2003, Murtinho and Hayes, 2011, Armitage, 2005, Tompkins and Adger, 2004, Adger et al., 2005). The relationship between CBNRM and individual adaptive capacity is of global concern given the ubiquity of CBNRM worldwide, the patent impacts of global changes at local levels, and the recent calls for the integration of climate and rural development policies (Eakin et al., 2014, Klein et al., 2005). So far, however, there have not been formal, large-n tests of that relationship.

This paper aims to address that gap by looking at farmers' responses to disturbances in community-based resource management regimes. The research questions that drive the research are: Are there identifiable patterns in the way farmers respond to different types of disturbances to their livelihoods? And, do community-based land and water management institutions affect the effectiveness of farmers' responses? To answer these questions the study adopts an integrative approach to the study of adaptation, i.e., one that (1) observes both climatic and socio-economic disturbances (Tucker et al., 2010, Murtinho and Hayes, 2011), and (2) explains the adaptive capacity of farmers (i.e., their capacity to respond to disturbances effectively) and its relation to 
CBNRM institutions by looking at proximate and more structural factors (Ribot, 2014, Eakin and Lemos, 2006).

Empirically, the study relies on a multi-level set of data obtained from irrigation farmers and Water User Associations (WUAs) in Mexico. Studying farmer's adaptive capacity in the context of Mexican irrigation systems is important for several reasons. Irrigated agriculture can represent a "win-win" solution to problems of environmental risk and poverty in rural areas in many countries, if proper natural resource management regimes are in place (Araral, 2013, Kerr, 2007). At the same time, irrigated agriculture -particularly in arid and semi-arid regions- is one of the economic activities where the impact of climatic and non-climatic events is most evident (Boken et al., 2005). Irrigation systems are managed by WUAs in many regions around the world. Indeed, much of the foundations of our current knowledge about community-based natural resource management relies on irrigation management studies (Agrawal, 2001, Poteete et al., 2010). Mexico is a flagship case of the turn towards CBNRM that many developing countries have gone through in the last decades (Subramanian et al., 1997). The process of decentralization in the irrigation sector, which involved most notably the creation and empowerment of WUAs at the local level (Vermillion, 1997), has been profiled internationally as a policy success (GarcesRestrepo et al., 2007, Rap and Wester, 2013). Also, the Mexican productive sector has been exposed to globalization, market liberalization, and climatic risk (Luers et al., 2003, Eakin, 2005), which constitute a typical combination of disturbances in developing regions (Adger et al., 2003, Eakin and Lemos, 2006). Finally, Mexico has one of the world's highest proportions of agricultural land under communal property (the ejido system) --approximately $57 \%$ of the irrigable area-- which offers a unique opportunity to study the influence of different combinations of land and water property regimes on adaptation.

\section{Farmer adaptive capacity and community-based natural resource management}

Adaptation has been defined as "changes in processes, practices and structures to moderate potential damages or to benefit from opportunities associated with climate change" (McCarthy et al., 2001). Meanwhile, adaptive capacity (also referred to as adaptation capacity) concerns not the observed changes but the system's predicted ability to carry out those actions to prepare and adapt to future disturbances (Smit and Wandel, 2006, Engle, 2011). Both, however, are intricately 
related: as Smit and Wandel (2006: 287) put it, "adaptations are manifestations of adaptive capacity". Hence, often adaptive capacity is analyzed ex-post based on the observed effectiveness of particular (adaptation) responses.

The farming sector is particularly vulnerable to disturbances of different kinds, to which farmers need to adapt via a variety of responses. Much is known about the individual factors that contribute to the effectiveness of farmer adaptation responses. Two of the most cited factors include economic resources and access to relevant information. Economic resources protect farmers from debt traps in the aftermath of ecological disasters and allow them to opt for highcost adaptation investments or favored coping options (Cardona et al., 2012, Eriksen et al., 2005, Liu et al., 2008, Reidsma et al., 2010, Vásquez-León et al., 2003). Having the right information, whether climatic, technological or institutional, increases risk awareness and allows farmers to make strategic choices and planning in preparation for disturbances (Vásquez-León et al., 2003, Phillips, 2003, Patt and Gwata, 2002, Ziervogel, 2004, Nhemachena et al., 2014, Wheeler et al., 2013). Less is known about the role of local collective action institutions, i.e., rules governing land and water resources, on the capacity of farmers to remain in business in the advent of disturbances. This gap is particularly noticeable in developing countries, where collective resource-management institutions are widespread (Agrawal, 2010), and where bottom-up adaptation experiences have traditionally been central to the resilience of vulnerable populations (Adger et al., 2003)

Water, e.g., irrigation, is managed through community-based, water user associations (WUA) in many countries around the world (Garces-Restrepo et al., 2007). The main function of the associations is to guarantee that their members get the water they need in the right quantity and timing. This depends on the ability of the users, e.g., farmers, to design rules for collective decision-making, water allocation, infrastructure maintenance, and conflict-solving. Monitoring and sanctioning ensure compliance with rules and therefore institutional performance (Meinzen Dick, 2007). In turn, institutional performance strengthens trust among the association members, makes their behavior more predictable and facilitates individual and collective planning (Ostrom and Walker, 2002, Ostrom, 1998, Folke et al., 2005, Grothmann and Patt, 2005). Droughts and other disturbance events increase the stakes over resource use and threaten the ability and willingness of users to cooperate (Blanco et al., 2015). In these contexts, enforcement can again 
be particularly important to guarantee sufficient compliance levels and the robustness of the management system (Villamayor-Tomas, 2014).

Authors studying the interaction of irrigation management regimes and land property have pointed to a variety of issues, including the positive impact of tenure security on irrigation investments (Hodgson, 2004); the water use efficiency implications of the appropriation versus riparian water rights doctrines (Rosegrant and Gazmuri, 1995); the negative impacts of statepromoted irrigation projects on land distribution and tenure security (Cotula, 2006); the effects of land use changes on water quantity and quality in riparian areas (Meinzen Dick and Nkonya, 2007); and the management implications of uncoordinated land and water management policies (Meinzen Dick and Nkonya, 2007). With very few exceptions, however, the impact of communal and private property of land on irrigation management has been scarcely explored (Akudugu and Issahaku, 2013, Onyango et al., 2007).

\section{Methods}

Methodologically, the paper falls in-between the positivist and constructivist approaches to adaptation (Ribot, 2014). Risk is understood as a tangible by-product of specific natural and social disturbances. At the same we recognize that "risks do not directly reflect natural reality but are refracted in every society through lenses shaped by history, politics and culture" (Jasanoff 1999, pp. 139; cited by Ribot 2014).

Specifically, the paper unfolds as an "anatomy of adaptation" (Smit et al., 2000), which seeks to (1) answer the questions of to what farmers adapt (i.e. specific disturbances ), and how (i.e. specific adaptation responses) (Murtinho and Hayes, 2011); and (2) explain the effectiveness of those adaptation responses by looking at both proximate (e.g., WUA performance) as well as structural factors (Ribot, 2014). While the analysis does not look directly at adaptive capacity, we take the effectiveness of the observed adaptation responses as indirect evidence of it.

Based on the reviewed theory, we expect WUA performance to positively affect farmer response effectiveness. We also expect that such effect holds after controlling for important farmer and Mexican context characteristics such as economic resources and information, and land tenure, 
respectively. The analysis relies on interviews with multiple stakeholders and survey data collected among farmers from 7 irrigation systems in two Mexican valleys. The data is first used to characterize the disturbances and responses identified by the farmers. Then, farmers' selfreported response effectiveness is explained via a logistic regression and discussed within the broader political economy context.

\subsection{Sampling}

The sampling of farmers followed a stratified and purposive selection strategy. The selection of valleys aimed at controlling for exposure to droughts. The valleys selected were the Yaqui Valle of Sonora and the Low Conchos Valley of Chihuahua, in Northwestern Mexico (see Figure 1 below). With a semi-arid climate, the states have a long tradition of irrigation. Also, major droughts hit both valleys between the second half of the 1990s and in 2006, with shorter water scarcity episodes in between and after (Naylor et al., 2001). 
Figure 1. Yaqui and Conchos valleys and selected irrigation systems

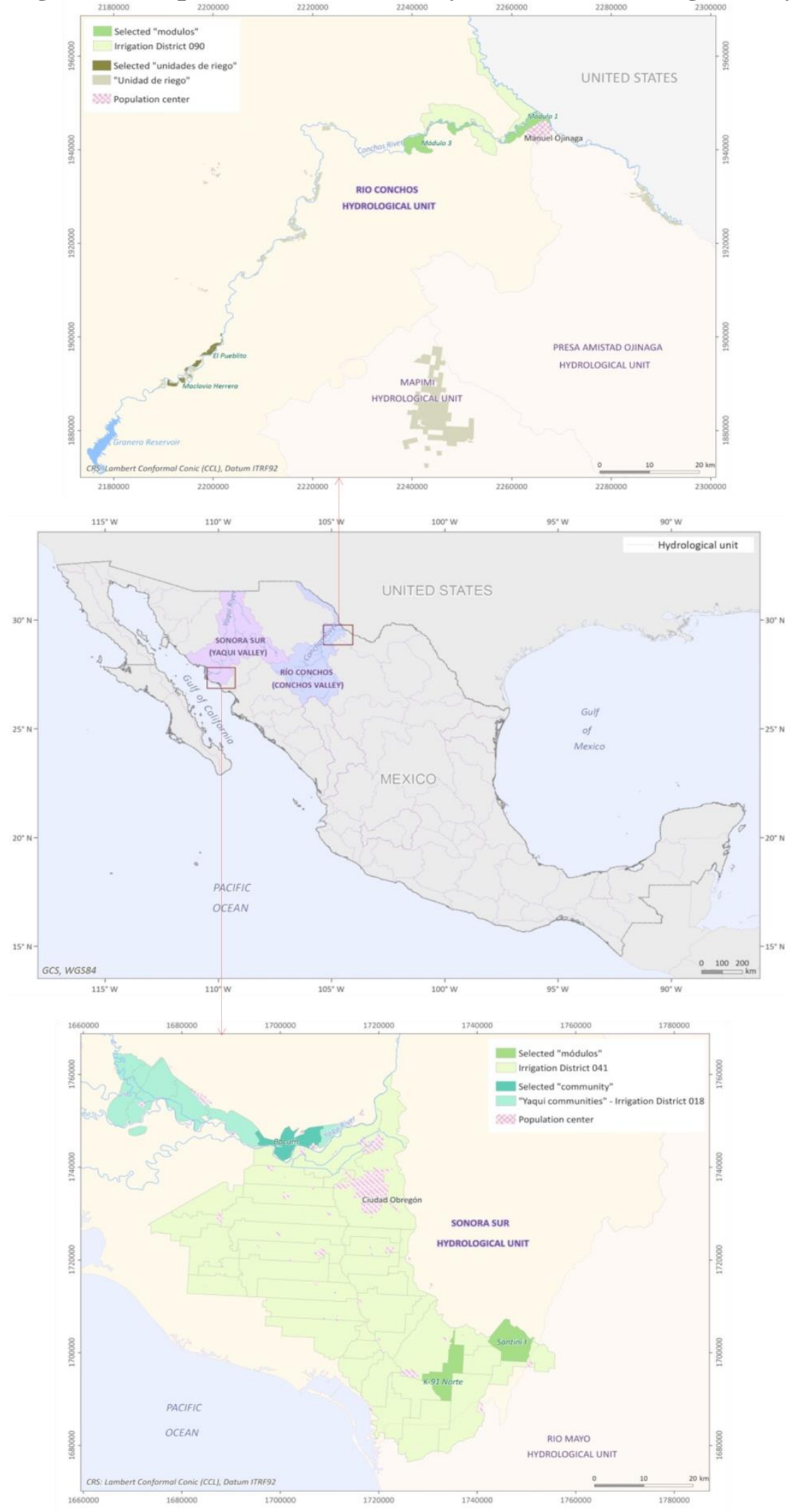

Source: own elaboration based on data from CONAGUA, Irrigation District 090, Irrigation District 041 
The selection of irrigation systems within each valley sought to control for the dominance of communal (i.e. ejido) versus private landholdings; and the cleavage between unidades vs. modulos (see Table 1). Current communal land systems in Mexico have their origins in the land reforms that began in the 1930s, when the government decided to devolve land property rights to local communities via the organization of common property regimes (heretofore ejidos). In the 1990s, as part of broad political and economic reforms and debates about the economic 'productivity' of communal property (Muñoz Piña et al., 2003), the government promoted a series of legal changes to facilitate the privatization of ejidos. The reforms have resulted in a mixed distribution of communal and private property land across irrigation systems.

Table 1. Sampling strategy

Conchos Valley (CHIH) Yaqui Valley (SON)

\begin{tabular}{|c|c|c|c|c|c|c|c|}
\hline \multirow{3}{*}{\begin{tabular}{|l|} 
Exposure \\
$\begin{array}{l}\text { Name of } \\
\text { District (\#) }\end{array}$ \\
$\begin{array}{l}\text { Name of } \\
\text { system }\end{array}$ \\
\end{tabular}} & \multicolumn{4}{|c|}{$\begin{array}{c}\text { Intensification, immigration, urban influence; } \\
\text { droughts }\end{array}$} & \multicolumn{3}{|c|}{$\begin{array}{l}\text { Economic decline, emigration, rural area; } \\
\text { droughts }\end{array}$} \\
\hline & \multicolumn{2}{|c|}{ Bajo Río Conchos (\#090) } & \multicolumn{2}{|c|}{$\begin{array}{l}\text { (Not applicable; } \\
\text { Unidades) }\end{array}$} & \multicolumn{2}{|c|}{ Río Yaqui (\#041) } & \multirow{2}{*}{$\begin{array}{c}\text { Colonias } \\
\begin{array}{c}\text { Yaqui } \\
(\# 018)\end{array} \\
\begin{array}{c}\text { Bacum } \\
\text { (locality) }\end{array}\end{array}$} \\
\hline & Modulo 1 & Modulo 3 & Pueblito & Maclovio & Modulo K-91 & $\begin{array}{l}\text { Modulo } \\
\text { Santini } 1\end{array}$ & \\
\hline $\begin{array}{l}\text { Property } \\
\text { regime }\end{array}$ & Private $98 \%$ & $\begin{array}{l}\text { Ejido } \\
68 \%\end{array}$ & $\begin{array}{l}\text { Private } \\
90 \%\end{array}$ & Ejido $90 \%$ & $\begin{array}{l}\text { Private } \\
100 \%\end{array}$ & Ejido $90 \%$ & $\begin{array}{l}\text { Communal* } \\
100 \%\end{array}$ \\
\hline $\begin{array}{l}\text { Irrigated } \\
\text { Area (has.) }\end{array}$ & 1,419 & 1,254 & 617 & 576 & 4,684 & 4,721 & $\sim 1,000$ \\
\hline $\begin{array}{l}\text { Number of } \\
\text { irrigators }\end{array}$ & 203 & 130 & 91 & 106 & 335 & 850 & NA** \\
\hline $\begin{array}{l}\text { Irrigators } \\
\text { surveyed }\end{array}$ & 25 & 23 & 19 & 27 & 25 & 31 & 18 \\
\hline
\end{tabular}

* In the course of fieldwork we found out that Bacum, and all other communities of the Yaqui tribe (Colonias Yaqui District), have a de facto private property regime in which $90 \%$ of all parcels are rented to mid- to large, non-Yaqui landowners, mostly from the nearby Yaqui District.

** Official data about number irrigators in the Bacum case was not available; however, according to estimations from informants, the number of active irrigators is not bigger than 50 .

Traditional water management systems in Mexico, or Unidades de Riego ("irrigation units", hereafter unidades), have traditionally enjoyed a great deal of autonomy. There are around 23,000 unidades in Mexico (covering 2 million hectares) registered by the Federal Water Agency (CONAGUA), and around 17,000 unregistered ones (900,000 hectares) (CONAGUA, 2012). 
State-promoted systems, also called Modulos de Riego ("irrigation modules", hereafter modulos) date in most cases from the second half of the $20^{\text {th }}$ Century, are grouped into bigger entities called Distritos de Riego ("irrigation districts", hereafter Distritos), and have been under the tutelage of the federal government until the late 1990s, when the government transferred management rights at the modulo level. Currently, there are 85 distritos in Mexico, covering 3.5 million hectares (CONAGUA, 2012).

We first carried out individual interviews with current and past WUA representatives, leaders of communities and ejidos, and CONAGUA and other governmental entities. We carried out a total of 33 interviews: 21 in Conchos ( 8 with government officials, and 13 with leaders and ex-leaders of the irrigation associations and ejidos; and 12 in Yaqui (4 with government officials, 6 with leaders of the irrigation associations and ejidos, 1 with a private enterprise owner, and 1 with university professor). The purpose of the interviews was to obtain an initial characterization of the main disturbances and collective responses in each irrigation system. Emphasis was made on tracing the processes through which collective responses to specific disturbances were developed, including the main actors involved, the main facilitating factors and barriers faced, and the perceived outcomes of these responses.

We then conducted the farmer survey in each of the seven irrigation systems. We aimed for a sample size of 25-30 farmers per system. Sampling was non-random due to the difficulties to have access to the entire population of farmers as well as to our interest in having enough representation of wealthier and poorer farmers. By these means we aimed at controlling for a potential selection bias in the assessments of collective water management and response effectiveness (see results section and Appendix A6 for a more detailed account of potential biases) $)^{1}$.

\footnotetext{
${ }^{1}$ Wealthier resource users shall not only have more resources to defend their individual interests in collective management processes (Baland and Platteau, 1999, Bardhan and Dayton-Johnson, 2001) and therefore have disproportionately positive opinions about the performance of said processes, but also be less vulnerable to disturbances (Adger, 1999) and feel particularly effective in adapting to those. Thus, we requested WUA leaders to provide us with lists of big and small farmers. In some cases, the community leaders contacted the producers directly.
} 
Our teams then set up appointments for the personalized delivery of the survey. Surveys were administered personally and in locations selected by the interviewees to maximize the response rate and to avoid biases associated to sensitive questions such as the evaluation of WUA performance. We completed 168 surveys out of the approximately 1,765 farmers within the 7 irrigation systems (sampling error of $7.2 \%$ ).

\subsection{Variables}

The survey addressed farmer and disturbances characteristics, and farmers' responses to the disturbances. Farmers were asked to rank the top three most problematic disturbances they had faced in the last 10 years and report how they responded to each of those disturbances. The effectiveness of farmers' responses was self-assessed by respondents based on 5 criteria, including whether the response (1) reached its objectives, (2) was implemented in a timely manner, (3) created negative externalities or (4) unattended effects, and (5) whether it would be used in the future (see Table A1 in Appendix for a list of all variables and survey items).

Analyses that include many variables can describe complex phenomena accurately; however, too many explanatory variables or very complex explanations make theory less meaningful (Agrawal, 2001, Cox, 2008). In this study we aimed to balance our interest in understanding a complex phenomenon like adaptation, with the urge to avoid excessively-complex, "garbagecan", surveys and models (Achen, 2002). We did not aim to explain collective action, but its influence on individual adaptation, along with key individual controls. To measure the performance of collective management we relied on CPR theory, and collected data on satisfaction with key management processes and compliance with rules of different kinds. The individual farmer adaptation literature was also helpful in the variable selection process as it is particularly clear about the influence of economic resources and access to information on adaptation. We used farm size as a proxy for economic resources (Leclère et al., 2013, Soule et al., 2000); however, we also collected data on other related variables, such as economic dependence on irrigation, reliance on credit to cultivate, and whether the farmer had benefited from a government support program in the recent past. To assess the information variable, we collected data on both the type and number of information sources used by farmers. 


\section{Characterization of disturbances, and responses}

\subsection{Water and market disturbances}

Figure 4 shows the most troubling disturbances as identified by farmers. Droughts were the most frequently mentioned disturbance in the surveys (21\%), with minor differences across the two valleys (22\% in the Conchos Valley, and $20 \%$ in the Yaqui Valley). The interviewed WUA and district representatives also pointed to droughts as the most important disturbance. Interviews also revealed a concern about reduction in water availability more generally. In the Yaqui valley, interviewees stressed that over the last 15 years, the winter rains, called equipatas, have completely disappeared. In the Conchos valley, interviewees tended to focus on the mismatch between allocated water use rights and water availability during droughts. Water availability in the area under study has indeed been recently affected by an increased competition over the resource due to the expansion of irrigation upstream of the valley, as well as the need to fulfill international water payment commitments with the US (Garrick et al., 2016).

Figure 4. Frequency of disturbance reports by farmers in the Yaqui and Low Conchos valleys

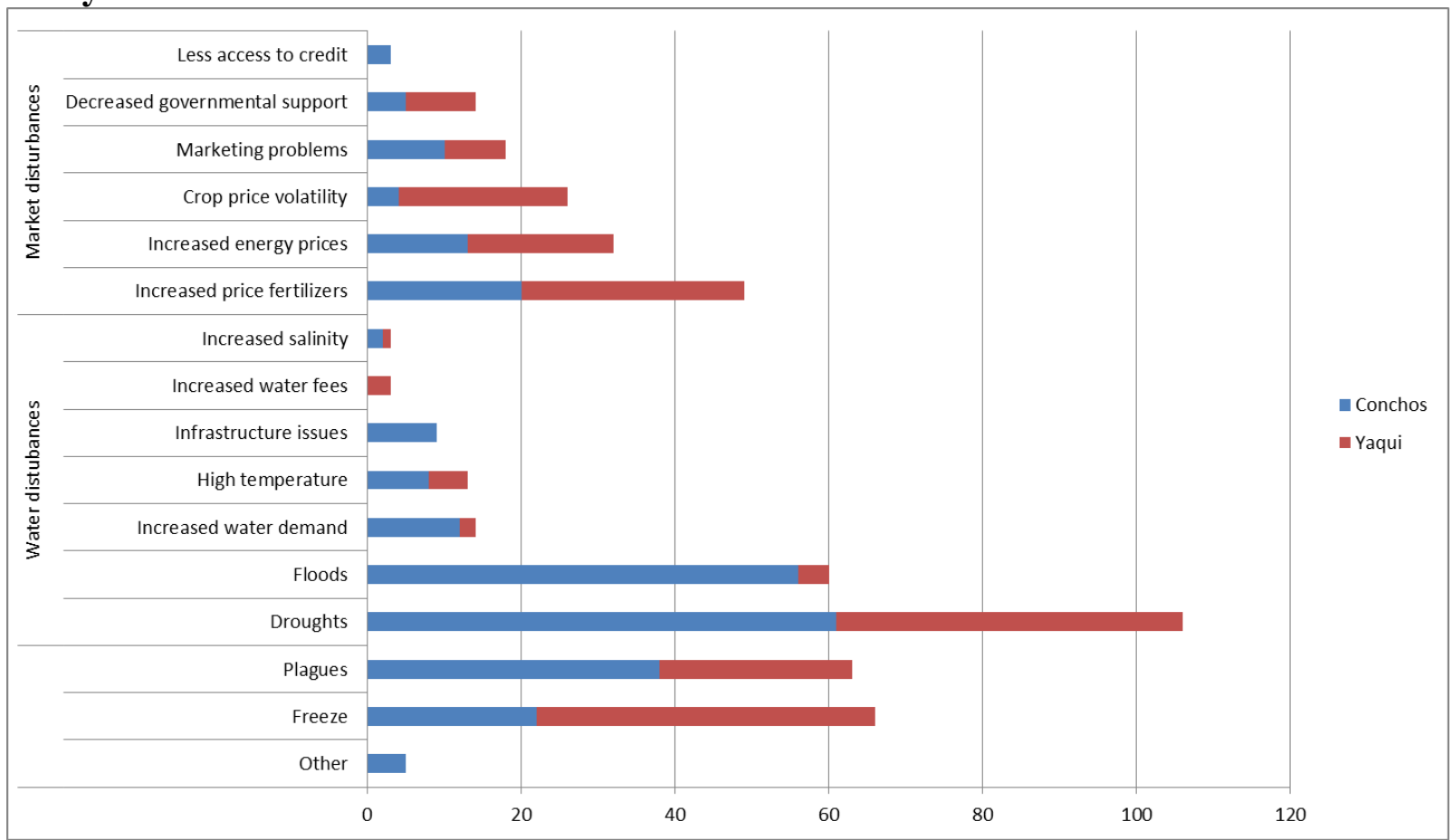

Note: the data here includes all reported disturbances, i.e., those ranked first, second and third in the survey. 
The data also displays a wide range of other biophysical, mostly water-related, disturbances, and market-related disturbances (see Figure 4). Here, differences between the two valleys are clearer than in the case of droughts. Most notably, there is a significant difference in the frequency of flood reports (20\% vs. $2 \%$ in the Conchos and Yaqui valleys, respectively; $99 \%$ confidence level as per chi-square and Fisher's exact tests). This can again be associated to the international water payment commitments between Mexico and the US, which sometimes require quick reservoir releases of water beyond the carrying capacity of the river (Garrick et al., 2016). Also importantly, around $40 \%$ of the farmers in the Yaqui valley pointed to market disturbances while only $24 \%$ did it in the Low Conchos valley (significant difference at $99 \%$ confidence as per chisquare and Fisher's exact tests). This difference can be associated to the strong marketintegration of farmers in the Yaqui valley (Matson et al., 2005).

According to the survey data, water-related disturbances had a significant impact on water distribution in the irrigation systems. Around $40 \%$ of respondents who reported water disturbances (see Figure 4) indicated a decrease in the performance of the water allocation in their irrigation system due to the disturbance. That was not the case for market-related disturbances (the percentage decreases to around 22\%; the difference is significant at the $99 \%$ confidence level asper chi-square and Fisher's exact test). Reports about the impact of water and market disturbances on farmers' quota payments to their associations were much less frequent and not substantively different from each other (27\% and $25 \%$, respectively). This was expected given that farmers' economic conditions and thus ability to pay the quotas is affected by aspects other than water productivity, such as crop market prices or input prices.

Among the most frequently mentioned disturbances, "droughts" were disproportionately ranked as most troubling (58\% of the times that "droughts" was mentioned); and "crop price volatility", "increase in energy prices" and "increase in fertilizer prices" were disproportionately ranked as least troubling $(58 \%, 53 \%$ and $55 \%$ of the times that those disturbances were mentioned, respectively). Not all farmers marked three disturbances; some of them (20) marked just two disturbances, generating missing data for the salience variable. Around $85 \%$ of such missing data concentrated on the "least troubling" value. 
Around $66 \%$ of the farmers who reported droughts as the most troubling disturbance also reported freezes, floods or plagues as the second most troubling disturbance. As indicated by interviewees, droughts in the areas of study tend to come with higher temperatures in winter which contribute to the proliferation of plagues. Stagnant water shall remain for months in the fields after floods, which also makes crops more vulnerable to plagues, as well as to infrastructure issues in the advent of freezes. Similarly, much of the vulnerability of farmers to market disturbances was associated by interviewees to the removal or reduction of government subsidies and price controls, the opening of the economy to US imports after the North American Free Trade Agreement (NAFTA), as well as historical trends in oil prices (Fox and Haight, 2010, Naylor and Falcon, 2012). The ex-President of one of the irrigation associations in the Conchos valley, for instance, noted that one of the main problems in his unit was commercialization, given the context of price instability, rising costs of inputs and declining government supportswhich he perceived as biased in favor of 'those with money'. He linked these disturbances with poverty and out-migration, and in turn to decapitalization (abandoned lots). Similarly, different interviewees in the Yaqui valley complained about the "lack of government protection against global market prices" and how quickly global price falls translated in liquidity problems and decapitalization for certain farmers. Indeed, in our sample, just $48 \%$ of the poorer farmers (those with smaller farms) reported having received agricultural support from the government in the past, while $78 \%$ of the wealthier farmers reported such supports (significant difference at the $99 \%$ level as per chi-square and Fisher's exact tests). Additionally, 67\% of all the reported market disturbances (and more than $75 \%$ of the "crop price volatility" and "increase in energy prices" disturbances) were identified by farmers from communal land-dominated irrigation systems (the remaining $33 \%$ were identified by farmers from private land-dominated systems; significant difference at $95 \%$ confidence level as per chi-square and Fisher's exact tests).

Finally, interview data points to couplings between water and market disturbances that produce wider-ranging effects. A frequently mentioned example in the Conchos valley was the confluence of droughts and punctuated crop price crises, like the one that partially provoked the collapse of the cotton production system in the late 1990s (Walsh, 2008). Interviewees also pointed how the land abandonment and impoverishment of certain groups of farmers had created difficulties to maintain the irrigation infrastructure in some systems due to lack of labor and non-compliance 
with quota payments. Another example is the interaction between droughts and the progressive increase of fertilizer prices that farmers from both valleys have been facing since after the dismantlement of government support for agriculture in the early 1990s.

\subsection{Responses to disturbances}

Table 2 shows the measures developed by farmers in response to water, market and other disturbances. The main responses to droughts and other water disturbances are change in water use (14\% of responses), change in farming strategies $(12 \%)$, request external support (10\%) and change in crops (9\%). Change in water use involves increasing the time between watering events or shortening them, reduce overall water consumption, and diversify sources of water (e.g. by installing a water well). Change in farming strategies include harvesting earlier, using different plowing techniques to maintain soil moisture, leveling land and other techniques. The request external support refers mostly to the reliance on federal disaster relief programs. Change in crops involves switching from higher water-demand crops such as corn or even wheat to lower water demand crops such as safflower and fallow land.

Table 2. Farmer responses to different types of disturbance

\begin{tabular}{lccc} 
& $\begin{array}{c}\text { Water } \\
\text { disturbances }\end{array}$ & $\begin{array}{c}\text { Market } \\
\text { disturbances }\end{array}$ & $\begin{array}{c}\text { Freeze, Plagues, and } \\
\text { other disturbances }\end{array}$ \\
\hline Change crops & $9 \%$ & $1 \%$ & $2 \%$ \\
Change in water use & $14 \%$ & $2 \%$ & $7 \%$ \\
Request external support & $10 \%$ & $15 \%$ & $5 \%$ \\
Changes in farming strategies & $12 \%$ & $7 \%$ & $4 \%$ \\
Reduce agricultural inputs & $0 \%$ & $13 \%$ & $1 \%$ \\
Look for new markets & $1 \%$ & $11 \%$ & $1 \%$ \\
Look for credit & $2 \%$ & $10 \%$ & $0 \%$ \\
Decapitalization & $4 \%$ & $3 \%$ & $1 \%$ \\
New investments & $2 \%$ & $1 \%$ & $6 \%$ \\
Other economic activity & $1 \%$ & $1 \%$ & $1 \%$ \\
Increase fertilizers & $0 \%$ & $2 \%$ & $3 \%$ \\
Increase pesticides & $1 \%$ & $1 \%$ & $29 \%$ \\
Increase production & $0 \%$ & $2 \%$ & $0 \%$ \\
Insurance & $0 \%$ & $1 \%$ & $4 \%$ \\
\hline Does not know & $5 \%$ & $3 \%$ & $5 \%$ \\
No adaptation response* & $37 \%$ & $27 \%$ & 134 \\
\hline TOTAL (n) & 211 & 151 & $28 \%$ \\
\hline NOt & & $1 \%$ & \\
\hline
\end{tabular}

Note: The data includes the main response to each of the 3 (in some occasions 2) disturbances the sampled farmers identified. See Table A2 in Appendix for an expanded version with the disturbances disaggregated. 
*A number of farmers reported no responding in any specific manner but just waiting and hoping for normal conditions to restore. Quotes included, from "I did not take any measures" and "I did not do much, just wait", to "what is one supposed to do?", or "there is no response against freezes".

Request external support and changes in agricultural techniques, were also frequently used to cope with market disturbances. Indeed external support was the most frequently mentioned response against market disturbances (15\%). Other popular responses to market disturbances include reduce agricultural inputs (13\%) such as fertilizer, gas, seeds and capital investments; look for new markets (11\%), which involves looking for new crop buyers and intermediaries, and marketing agricultural byproducts (e.g., hay for fodder); and credit (10\%), which refers to the recourse to new, both formal and informal, sources of credit, and loan overdraft.

Regarding responses to other disturbances, almost the totality of the increase pesticide responses (29\%) addressed the plagues disturbance. Responses to freezes, were quite evenly distributed, including insurance, request external support, change farming strategies, and new investments. Finally, a considerable percentage of irrigators reported not having implemented any response. This percentage reached $37 \%$ for water disturbances, and decreased to $27 \%$ and $28 \%$ for market and other disturbances, respectively.

Generally, famers self-assessed their responses as effective. This result was somehow expected: the sample included only farmers who are still in business and have enjoyed some minimum level of success in adapting to disturbances. That said, only $56 \%$ of all farmers who reported responses to droughts were fully satisfied (i.e., a positive scoring in all evaluative criteria). As shown in Figure 5, there were no notable differences between the effectiveness scores across disturbances. Responses to water infrastructure issues were assessed the most positively (71\% of farmers who faced this disturbance were fully satisfied with their responses), followed by responses to floods, increased water fees and increased salinity (67\% of farmers were fully satisfied with their responses to each disturbance). Responses to increased water demand, increased price fertilizers, increased energy prices and marketing problems scored the lowest (50\% each). 


\section{Figure 5. Percentage of farmers reporting full response effectiveness for different disturbances}

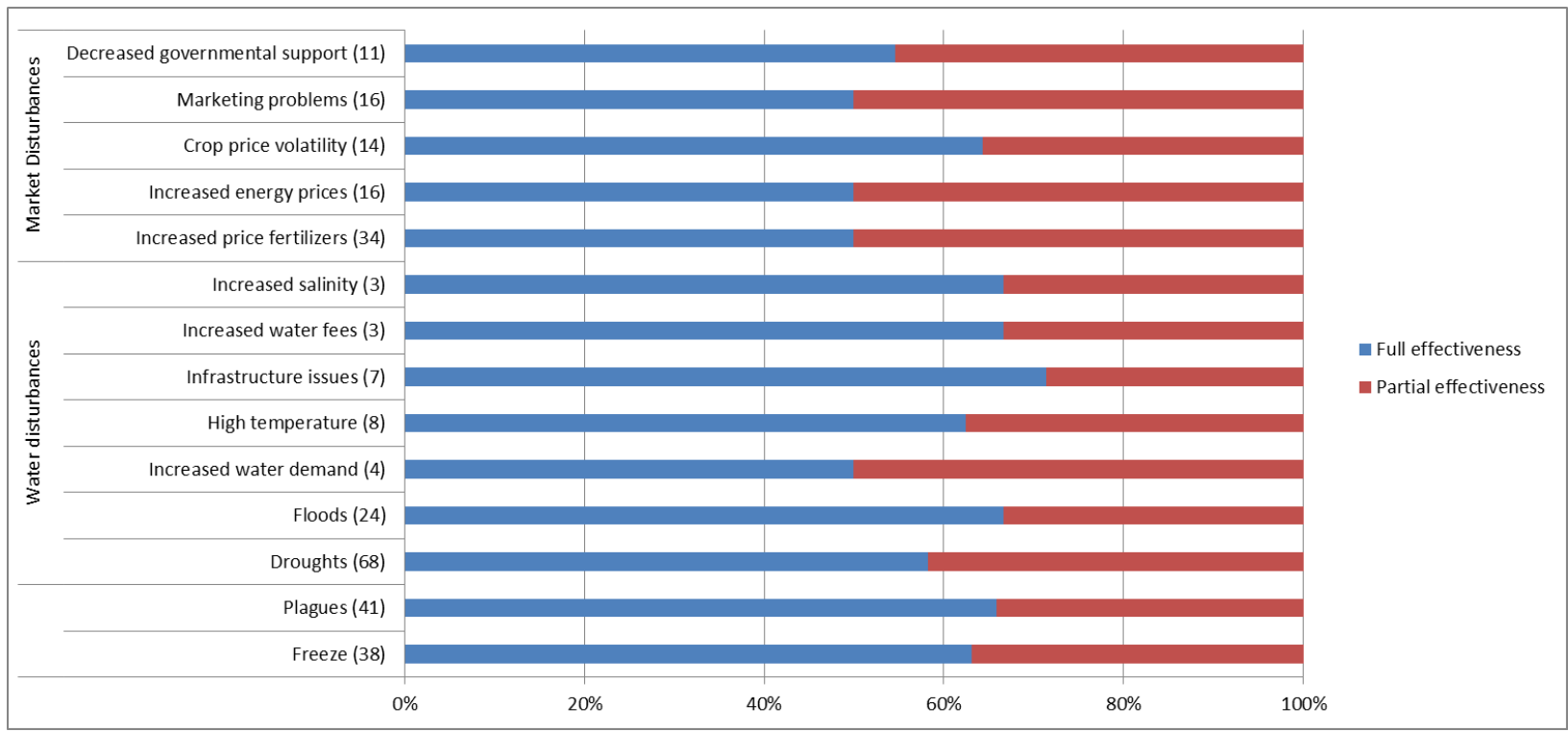

Note: The "less access to credit" disturbance is not included due to lack of data $(n=1)$. The number of observations for each disturbance is in parenthesis.

A focus on the case of droughts during the interviews revealed the existence of a number of collective responses (technical, capacity-building, institutional and political) developed by the irrigation associations (see Table A3 in Appendix). Technical responses consisted mostly of infrastructure improvements with the support of CONAGUA and the Federal Department of Agriculture (SAGARPA), either directly (in the case of unidades) or indirectly through the distritos (in the case of modulos and Bacum). An example of the capacity-building responses is the training programs developed by the government in collaboration with irrigation associations for improving the efficiency of cropping and irrigation practices. Two important institutional responses developed by CONAGUA in both valleys consisted on the ad hoc reduction of water rights to irrigation systems during severe droughts (in 2002-2003), and the permanent prohibition of cultivating more than two crops per year. An example of institutional responses at the District level (in District 41) is the reduction from 5 to 4 the number of irrigation turns allocated to farmers to guarantee that enough water remains until the end of the irrigation campaign during droughts. Other collective responses include the strengthening of information sharing and water use monitoring and sanctions, and the use of incentives to promote best irrigation practices. Finally, political responses consist mainly of claims of liability and lobbying activities carried out by the irrigation associations to guarantee that public authorities respect their water use rights in 
the advent of droughts or competing water uses, and that disaster and other funds are allocated in a timely manner.

\section{Regression analysis of farmers' response effectiveness scores}

To explain farmers' self-reported scores of response effectiveness we carried a series of logit regression models. In order to maximize variation, response effectiveness was operationalized as a dummy, where $1=$ all effectiveness indicators are positive, and $0=$ at least one effectiveness indicator is negative (see Table A4 in Appendix for alternative operationalizations). All the variables were also coded as dummies to facilitate interpretation (see Tables A5 in Appendix for detailed description). All models included dummies and robust cluster errors to control for the hierarchical nature of the dataset (farmers grouped into systems and valleys) (Cameron and Miller, 2015).

Given that the irrigation systems were not selected randomly, the statistical significance of the models and coefficients should be taken with caution, i.e., as a representation of the 7 systems and similar systems rather than as a general pattern. Also, the farmer sample size was just appropriate (sampling error $=7.2 \%$ at $95 \%$ confidence level) which also entails representation issues. Moreover, our analysis was particularly vulnerable to three types of well-recognized biases in social science research, to wit, selection-bias (Cook and Campbell, 1979), omitted variable bias (Rabe-Hesketh and Skrondal, 2008) and self-report bias (Podsakoff and Organ, 1986). As further explained in the Appendix (A6), we aimed to downplay those biases by combining the stratified sampling, the cluster errors modelling, and the use of multiple measurement items, among other strategies.

We ran three models explaining farmers' response effectiveness scores against water disturbances (droughts, floods, increased water demand, high temperatures), market disturbances (marketing problems, increased energy prices, crop price volatility, increased price of fertilizers, decreased governmental support), and all disturbances (Table 3). As shown in Model 1, response effectiveness scores to droughts and other water disturbances are higher in WUAs that perform very satisfactorily and is lower in systems with predominance of communal land. Being a wealthier farmer has a positive impact on response effectiveness, while having depended from 
government support in the past and relying on a diversity of information sources has a negative impact; however, none of these variable is statistically significant. Also, the benevolence of disturbances (i.e., whether farmers ranked them as least problematic) has positive and significant effects; and farmers who are located in the Conchos valley significatively report lower effectiveness scores than those in the Yaqui valley.

Table 3. Logistic regression models of farmers' response effectiveness scores

\begin{tabular}{lccc} 
VARIABLES & $\begin{array}{c}\text { M1: Water } \\
\text { disturbances }\end{array}$ & $\begin{array}{c}\text { M2: Market } \\
\text { disturbances }\end{array}$ & $\begin{array}{c}\text { M3: All } \\
\text { disturbances }\end{array}$ \\
\hline System and farmer features & & & \\
WUA Performance & $1.354^{*}$ & 0.578 & $1.224^{* * *}$ \\
& $(0.630)$ & $(0.883)$ & $(0.211)$ \\
Communal land & $-0.914^{* * *}$ & -0.537 & $-0.613^{* *}$ \\
Economic resources (large farm) & $(0.135)$ & $(0.452)$ & $(0.128)$ \\
& -0.629 & $1.726^{* * *}$ & 0.435 \\
Information diversity & $(0.514)$ & $(0.380)$ & $(0.259)$ \\
& 0.0187 & $-0.689 *$ & -0.441 \\
Controls & $(0.485)$ & $(0.290)$ & $(0.343)$ \\
Government support recipient & & & \\
& 0.0727 & $-1.872^{* * *}$ & -0.470 \\
Disturbance benevolence & $(0.868)$ & $(0.548)$ & $(0.446)$ \\
& $0.747 * * *$ & 0.426 & $0.291 * *$ \\
Valley (Conchos) & $(0.241)$ & $(0.349)$ & $(0.139)$ \\
& $-1.973 * * *$ & $-1.027 * *$ & $-1.093^{* *}$ \\
Constant & $(0.228)$ & $(0.418)$ & $(0.183)$ \\
$\mathrm{R}^{2}$ & & & \\
Observations & $0.789 *$ & $0.956^{*}$ & $0.834^{* * *}$ \\
\hline
\end{tabular}

Robust standard errors in parentheses (note that these errors are only approximate; the errors used to make inference were recalculated following Webb's (2013) procedure, which were bigger than those in this table.

$* * * \mathrm{p}<0.01, * * \mathrm{p}<0.05, * \mathrm{p}<0.1$

Note 1: Observations in these models are not farmers but responses to disturbances (see also note to Table 2 above). Note 2: Model 1 was tested including also freezes, floods and plagues with very similar results; however, qualitative data did not allow us to understand the mechanisms through which WUAs contribute to response effectiveness against those disturbances so we decided to add them in an "all disturbances" model (M3) instead.

Note 3: We also run alternative models including economic dependence on irrigation and reliance on credit for cultivation as individual level controls (see Table A1 to see survey items, and Table A5 for descriptive statistics). These variables did not have a substantive nor statistically significant impact and the results with regard to the other variables did not change. 
As shown in Model 2, neither WUA performance nor land property have a strong impact on response effectiveness scores in the context of market disturbances. Coefficients of both variables point in the same direction than in Model 1; however, the significance, is considerably lower in Model 2 both substantively and statistically. Alternatively, having economic resources (i.e., large farm), having benefited from governmental support programs, and having access to a diversity of information sources both have a strong and significant effect. The impact of being recipient of government support is negative, which can be interpreted in light of the recent decrease of said support and neoliberal reforms in Mexico. As further discussed below, farmers used to receiving governmental support would be more vulnerable to the economic disturbances stemming from the new neoliberal context than those accustomed to operate without such support. The effect of information diversity is also negative. This unexpected result can be further qualified. The most popular sources of information in this subsample were the "media" (50\%), "neighbors" (38\%), the WUA (30\%) and the "government" (18\%). None of these variables had a significant impact when added to the model via dummies; however the "neighbors", "media" and "government" variables had a negative impact, while the WUA variable had a positive one.

\section{Table 4. Predicted impact on response effectiveness}

\begin{tabular}{llll} 
& Water disturbances & Market disturbances & All disturbances \\
\hline WUA performance & $+27 \%$ & -- & $+24 \%$ \\
Communal land & $-21 \%$ & -- & $-15 \%$ \\
Economic resources (large farm) & -- & $+40 \%$ & -- \\
Information diversity & - & $-18 \%$ & -- \\
Government support recipient & -- & $-41 \%$ & -- \\
Benevolence & $+30 \%$ & -- & $+14 \%$ \\
Valley (Conchos) & $-40 \%$ & $-25 \%$ & $-23 \%$ \\
\hline
\end{tabular}

Note: probability changes have been calculated only for the statistically significant variables. The scores represent percentage change in probability of effectiveness, holding all the other variables at their means.

Table 4 reports predicted impact of the model variables on response effectiveness. According to the estimations, farming in a highly performing WUA would increase the chances of response effectiveness against droughts and other water disturbances by $27 \%$ on average, while doing it in a communal land-dominated system or in the Conchos valley would decrease response effectiveness by $21 \%$ and $40 \%$ respectively. In the context of market disturbances, the importance of resource management institutions would be superseded by farmer features, including differences in economic resources, having depended on government support in the past, 
and having access to different sources of information. Wealthier farmers (larger farm sizes) have an average of $40 \%$ higher chance of having an effective response than poorer farmers; while farmers relying on more than one source of information and farmers having depended on government support in the past have up to $18 \%$ and $41 \%$ lower chances, respectively.

By the same token, the average predicted probability of responding effectively to disturbances shall vary considerably depending on different combinations of farmer and collective features and the type of disturbance. For example, the probability that farmers respond effectively to water disturbances could range from to $30 \%$ in a communal-dominated system in the Conchos valley (like the cases of "Maclovio" and "Modulo 3") if this were managed by a low-performing WUA, to $97 \%$ in a system dominated by private land in the Yaqui valley (like the case of "Modulo K91") if this were managed by a highly-performing WUA. Also, wealthier farmers who did not depend on government support in the past and rely on one source of information would have around $95 \%$ chances of being effective against market disturbances, while poorer farmers who depended on government support in the past and rely on multiple sources of information would have a $37 \%$ chance.

\section{Discussion}

Overall, the above findings support but also qualify expectations about the contribution of community-based resource management institutions to farmer adaptive capacity. The paragraphs that follow discuss the findings with regard to the distinction between water and market disturbances, the scope of cooperative measures developed within the context of WUAs, and the political-economic context of communal land management in Mexico and other developing countries.

\subsection{Coupled natural resource and global market disturbances}

Rural populations in developing regions are typically exposed to a number of socio-economic disturbances -market volatility, changing policies and other political economy conditions- that add to the potential impacts of climate changes (Eakin and Lemos, 2006, Turner et al., 2003). In these contexts, farmers may not perceive climatic disturbances as particularly threatening or more problematic than other disturbances (Eakin, 2005). Just $43 \%$ of the farmers in this study showed 
concern about natural resource (i.e., water) related disturbances, which was not expected given the recent history of water shortages in both valleys and the strong dependence of farmers on water. It is likely that the effectiveness of past responses to droughts (Barrios et al., 2009) and/or a process of normalization (Tucker et al., 2010), have reduced sensitivity of farmers to climate events. However, it is also likely that farmers are less prone to fear those events when experienced in combination with other events such as market changes. Indeed, resource and market disturbances are more frequently interlinked than not, "such that it is very difficult to separate impacts or to ascribe independent stimuli for adaptations" (Smit et al., 1996). As further illustrated below (see sections 6.3 and 6.4), the couplings between punctuated droughts and floods on the one hand, and decreasing terms of trade on the other, can be felt at both the farm and community levels, and unfold through complex mechanisms.

\subsection{Grappling with adaptation and development?}

Adaptive capacity cannot be considered simply an issue of the ability of individuals, i.e., farmers, to just adapt to pertinent risks, but rather to engage in livelihood activities that guarantee both their economic development and resilience in the long term (Eakin, 2005, Adger et al., 2003). In our analysis, farmer responses tended to cluster around resource (mostly water) disturbances and market disturbances. Water disturbances were mostly addressed via water conservation strategies, while market disturbances were tackled mostly via cost-saving, financial and product innovation strategies. Trade-offs between adapting to the two types of disturbances revealed tensions, some of which echo the dichotomy between adaptation to climate events and longer-term sustainable development (Brown, 2011, Eriksen and O'BRIEN, 2007, Klein et al., 2005). As pointed out by farmers, the change of crops in the advent of droughts, i.e. from high to low water demand and value crops, reduces the capacity of farmers to generate revenue, and in turn decreases their chances to access credit to cope with the decreased profitability of agriculture (see Table A2 in Appendix $)^{2}$. Similarly, the strategy of reducing agricultural inputs to cope with increased fertilizer and energy prices is in conflict with that of investing in new farming strategies such as leveling the land to better cope with floods, or the need to increase the use of use pesticides to cope with plagues.

\footnotetext{
${ }^{2}$ This finds historical evidence in the Conchos valley, where the cotton crisis and subsequent droughts pushed farmers to switch from cotton to lower-value crops making them financially more vulnerable to global market threats and ultimately paving the way for the economic decline of the valley (Walsh, 2008)
} 
Despite these trade-offs, the data also points to the potential synergies among responses within the same disturbance cluster. Water management changes, for example, are effectively used to cope with droughts and increases in water demand, as well as infrastructure issues (e.g. maintaining irrigation canals) and temperature raises (see "changes in water use" Table A2 in Appendix). Similarly, the search of new sources of funding and markets are used to cope with the increase in the price of fertilizers and energy, as well as market access difficulties, or the lack of governmental support. Although these synergies do not necessarily ameliorate the trade-offs, they provide guidance to design and implement climate-adaptation and development policies.

\subsection{Sustaining community-based water institutions and specific adaptive capacity}

The positive relationship between the performance of WUA institutions and the effectiveness of farmer adaptation responses to water disturbances illustrates the existence of important feedbacks from the collective level to the individual level and the importance of integrating the study of adaptation and natural resource governance (Murtinho and Hayes, 2011). The main role of the studied WUAs is to guarantee that farmers are not limited by water-related issues in their agricultural activities, which includes adapting to climatic disturbances. The insights gained through the interviews about how the WUAs manage droughts are illustrative of such role (see also Table A3 in Appendix). First, WUA cadres collect information about climate conditions, measures to improve water use, and government programs that can contribute to finance those measures. This information is in turn shared in assemblies as well as through everyday interactions and written communications. Second, the enforcement of water appropriation rules increases the reliability of water availability in the systems and, in turn, the capacity of farmers to plan for adaptation investments. Finally, WUA financing rules provide a way to pool labor and monetary resources to maintain the irrigation infrastructure and develop new infrastructure in the advent of disturbances. All of these functions have been documented in previous studies to explain the ability of resource-dependent communities to avoid resource overexploitation (Ostrom, 1990, Meinzen Dick, 2007), and develop collective adaptations (Murtinho and Hayes, 2011), but had not been related so far to individual adaptive capacity. The distinction between generic and specific adaptation capacities (Lemos et al., 2013, Eakin et al., 2014) can be useful for that purpose. Generic capacities include structural aspects such as income, health and 
education level, and are usually associated to development policies. Specific capacities, in turn, are tailored to particular risks (e.g., access to water supply and conservation solutions in the advent of droughts) and have usually been the focus of climate change adaptation policies (Eakin et al., 2014). According to the evidence from this study, WUAs can play a key role as providers of specific adaptive capacity (i.e., to cope with water-related climatic disturbances). However, as discussed in the next section, the relationship between CBNRM and adaptive capacity is not just one-way.

\subsection{Communal land property and poverty dynamics}

The negative association between communal land property and the effectiveness of adaptation responses to water disturbances hints at the importance of generic adaptive capacity and the complex paths through which it affects climate change adaptation. In this study, ejido farmers performed worse than the rest when adapting to water issues, even after discounting the effect of WUA management institutions and economic resources. Structural factors such as difficulties in obtaining access to credit and inputs, lack of governmental support, poverty, and tenure insecurity, have been shown to constrain agricultural productivity in communal lands in developing countries (Palmer and Bennett, 2013, Kerekes and Williamson, 2010, Logan and Moseley, 2002, Gyasi, 1994, Robson and Nayak, 2010). In the Mexican irrigation context, authors have additionally pointed to the undue influence of some farmers over water allocation, the management challenges of dealing with a large numbers of small farmers, and the difficult access to credit, improved seeds and other resources (Liverman, 1999, Alvarado, 2008, Turner et al., 2003, Vásquez-León et al., 2003). As reported by interviewees in our ejido cases, the small size of farms (usually less than 5 ha per farmer) hinders the development of scale economies and investments in technological or infrastructural improvements, such as drip irrigation or the leveling of land; and the impoverishment of farmers creates infrastructure maintenance issues. So, although the lower response effectiveness of farmers in communal lands holds even after controlling for economic assets, these still matter, as a large number of small, impoverished farmers may affect the effectiveness of other farmers indirectly through their impact on the performance of water user associations. 
In contrast to these results, we did not find conclusive evidence about the impact of WUA performance or communal land on the effectiveness of farmer adaptation responses in the context of market disturbances. This can be related to the very nature of those disturbances. On the one hand, it seems intuitive that WUAs are less concerned with issues that are related to the private assets of farmers rather than with water or other common pool resources. On the other hand, as further developed in the next section, market disturbances can be associated to the recent history of economic liberalization in the country, which has affected individual farmers and ejidos simultaneously. Thus, it is expected that, struggling with the same underlying background of events, ejido organizations play little role in farmer's adaptive capacity. Still, our market disturbance model shows a strong positive impact of economic resources on response effectiveness, which points again to the importance of generic adaptive capacity.

\subsection{Market disturbances and the withdrawal of the state}

Lastly, as pointed by other scholars, it is imperative that analyses of adaptive capacity go beyond identifying local proximate factors (e.g. resource use and management, economic resources), to identifying how these factors come to be produced -i.e. the larger-scale, underlying politicaleconomic conditions which mediate how resources and power are distributed- as well as to understanding farmers' ability to alter these conditions (Eriksen et al., 2015, Ribot, 2014). Both the exposure of farmers to market disturbances and the adaptive capacity deficits in communal lands can be traced back to the land and economic reforms carried out by the Mexican government since the 1990s. PROCAMPO, the main program to compensate farmers for the NAFTA agreement and the opening of the economy to global exports, has ended up disproportionally benefiting mid to large farmers and agribusiness, and thus has done little to offset the higher loss of higher crop prices and impoverishment of small farmers (Fox and Haight, 2010). The banking reforms affected BANRURAL (National Rural Credit Bank), reducing expenditures on subsidized credit, making it harder for small private and communal land farmers to obtain loans (Turner et al., 2003). Finally, the constitutional reform and the landtitling program PROCEDE in the 1990s facilitated the formalization of private land rights within communal land systems and fostered out-migration from rural areas (De Janvry et al., 2015). This in turn jeopardized the capacity of communal land organizations to carry their daily operations and weakened the adaptive capacity of remaining communal resource users (Vásquez-León et al., 
2003, Robson and Berkes, 2011). In our study, multiple sources of evidence point to the negative influence of the above political economy conditions on adaptive capacity. As pointed in section 5.1 , much of the vulnerability of certain farmers to market disturbances (e.g., the increase in input prices, volatility of prices) was associated by interviewees to the reduction of government support and the liberalization of the economy. Also, according to the survey data, poorer farmers have lower access to government support and, together with farmers who depended on such support in the past and ejido farmers, are less effective in coping with the consequences of the liberalized market.

\section{Conclusions}

This study contributes in two original ways to the study of adaptation to regionally- and globallylinked changes in rural contexts. First, it offers an inventory and systematic analysis of disturbances of different nature. Water and other climatic disturbances are perceived as a relatively salient problem, which is intuitive given the irrigated agriculture context; however, there are also a large number of other disturbances, many of which can be associated to the recent political economy history of Mexico and other developing countries in the era of globalization. We found couplings between water disturbances and global market disturbances, as well as tradeoffs between responding to one type of disturbance or the other; however, we also found promising synergies among responses to water disturbances and among responses to market disturbances. Second, the study tackles cross-scale adaptation dynamics by looking at the influence of communal land property and the performance of water user associations (WUAs) on the response effectiveness of farmers. Here we shed light on the provision of water-specific adaptive capacity by WUAs to farmers, and the negative impact that structural deficits associated to the liberalization reform and its impact on communal land property regimes have on farmers' generic adaptive capacity.

The reduced intervention of the state and concomitant decentralization of decision making at local levels have given rise to new spaces for action in developing countries but also left rural local communities fully exposed to globalization threats. From this perspective, it is contradictory that the state reduces its role in agricultural development policy while simultaneously reinvesting in climate change adaptive capacity. Paradoxically enough, this is particularly prevalent in developing countries, where those development policies are most needed. Reversing this trend 
means a far closer integration between adaptation programs and redistribution policy that is often supposed. Policies that strengthen the autonomy and capacity for cooperation of WUAs and ameliorate structural deficits in communal land regimes shall not only guarantee a longadvocated path to sustainable development, but also help farmers deal with some of the climatic uncertainties that persistently and increasingly threaten agriculture. 


\section{References}

Achen, C. H. 2002. Toward a New Political Methodology: Microfoundations and ART. Annual Review of Political Science, 5, 423-450.

Adger, N. 2003. Social Capital, Collective Action and Adaptation to Climate Change. Economic Geography, 79, 387-404.

Adger, N., Arnell, N. W. \& Tompkins, E. L. 2005. Successful adaptation to climate change across scales. Global Environmental Change, 15, 77-86.

Adger, N., Huq, S., Brown, K., Conway, D. \& Hulme, M. 2003. Adaptation to climate change in the developing world. Progress in development studies, 3, 179-195.

Adger, W. N. 1999. Social vulnerability to climate change and extremes in coastal Vietnam. World development, 27, 249-269.

Agrawal, A. 2001. Common Property Institutions and Sustainable Governance of Resources. World Development, 29, 1649-1672.

Akudugu, J. A. \& Issahaku, M. 2013. Dynamics of land ownership and management in smallscale irrigationschemes in the Bawku East district of Ghana European Scientific Journal, 9.

Alvarado, E. 2008. Poverty and inequality in Mexico after NAFTA: challenges, setbacks and implications. Estudios fronterizos, 9, 73-105.

Anderies, J. M., Janssen, M. \& Ostrom, E. 2004. A framework to analyze the robustness of social-ecological systems from an institutional perspective. Ecology and Society, 9, 18.

Araral, E. 2013. What makes socio-ecological systems robust? An institutional analysis of the 2,000 year-old Ifugao society. Human Ecology, 41, 859-870.

Armitage, D. 2005. Adaptive capacity and community-based natural resource management. Environmental management, 35, 703-715.

Baland, J.-M. \& Platteau, J.-P. 1999. The Ambiguous Impact of Inequality on Local Resource Management. World Development, 27, 773-788.

Bardhan, P. \& Dayton-Johnson, J. 2001. Unequal Irrigators: Heterogeneity and Commons Management in Large-Scale Multivariate Research. In: Ostrom, E., Dietz, T., Dolsak, N., Stern, P. C., Stonich, S. \& Weber, E. U. (eds.) The Drama of the Commons. Wahington DC: National Academy Press.

Barrios, J. E., Rodríguez-Pineda, J. A. \& De La Maza Benignos, M. 2009. Integrated river basin management in the Conchos River basin, Mexico: a case study of freshwater climate change adaptation. Climate and Development, 1, 249-260.

Blanco, E., Lopez, M. C. \& Villamayor-Tomas, S. 2015. Exogenous degradation in the commons: Field experimental evidence. Ecological Economics.

Boken, V. K., Cracknell, A. P. \& Heathcote, R. L. 2005. Monitoring and Predicting Agricultural Drought, New York, Oxford University Press.

Brown, K. 2011. Sustainable adaptation: An oxymoron? Climate and Development, 3, 21-31.

Cameron, A. C. \& Miller, D. L. 2015. A practitioner's guide to cluster-robust inference. Journal of Human Resources, 50, 317-372.

Cardona, O.-D., Van Aalst, M. K., Birkmann, J., Fordham, M., Mcgregor, G. \& Mechler, R. 2012. Determinants of risk: exposure and vulnerability. In: C.B. Field, V. Barros, T.F. Stocker, D. Qin, D.J. Dokken, K.L. Ebi, M.D. Mastrandrea, K.J. Mach, G.-K. Plattner, S.K. Allen, Tignor, M. \& Midgley, P. M. (eds.) A special report of working groups I and II of the Intergovernmental Panel on Climate Change (IPCC). Cambridge: Cambridge University Press. 
Conagua 2012. Estadísticas Agrícolas de los Distritos de Riego. Mexico, D.F.: Comisión Nacional del Agua.

Cook, T. D. \& Campbell, D. T. 1979. Quasi-experimentation: Design and analysis issues for field settings Boston, Houghton Mifflin Co.

Cotula, L. 2006. Land and water rights in the Sahel: tenure challenges of improving access to water for agriculture, IIED.

Cox, M. 2008. Balancing accuracy and meaning in common-pool resource theory. Ecology and Society, 13, 44.

Cox, M. 2014. Modern disturbances to a long-lasting community-based resource management system: The Taos Valley acequias. Global Environmental Change, 24, 213-222.

De Janvry, A., Emerick, K., Gonzalez-Navarro, M. \& Sadoulet, E. 2015. Delinking land rights from land use: Certification and migration in Mexico. The American Economic Review, $105,3125-3149$.

Eakin, H. 2005. Institutional change, climate risk, and rural vulnerability: Cases from Central Mexico. World Development, 33, 1923-1938.

Eakin, H. \& Lemos, M. C. 2006. Adaptation and the state: Latin America and the challenge of capacity-building under globalization. Global Environmental Change, 16, 7-18.

Eakin, H., Lemos, M. C. \& Nelson, D. R. 2014. Differentiating capacities as a means to sustainable climate change adaptation. Global Environmental Change, 27, 1-8.

Eakin, H., Tucker, C. \& Castellanos, E. 2006. Responding to the coffee crisis: a pilot study of farmers' adaptations in Mexico, Guatemala and Honduras. Geographical Journal, 172, 156-171.

Engle, N. L. 2011. Adaptive capacity and its assessment. Global Environmental Change, 21, 647656.

Eriksen, S. H., Brown, K. \& Kelly, P. M. 2005. The dynamics of vulnerability: locating coping strategies in Kenya and Tanzania. The geographical journal, 171, 287-305.

Eriksen, S. H., Nightingale, A. J. \& Eakin, H. 2015. Reframing adaptation: the political nature of climate change adaptation. Global Environmental Change, 35, 523-533.

Eriksen, S. H. \& O'brien, K. 2007. Vulnerability, poverty and the need for sustainable adaptation measures. Climate policy, 7, 337-352.

Feola, G., Lerner, A. M., Jain, M., Montefrio, M. J. F. \& Nicholas, K. A. 2015. Researching farmer behaviour in climate change adaptation and sustainable agriculture: Lessons learned from five case studies. Journal of Rural Studies, 39, 74-84.

Fleischman, F., Boenning, K., Garcia-Lopez, G. A., Mincey, S., Schmitt-Harsh, M., Daedlow, K., Lopez, M. C., Basurto, X., Fischer, B. \& Ostrom, E. 2010. Disturbance, response, and persistence in self-organized forested communities: analysis of robustness and resilience in five communities in southern Indiana. Ecology and Society, 15, 9.

Folke, C., Hahn, T., Olsson, P. \& Norberg, J. 2005. Adaptive governance of Social-Ecological Systems. Annual Review of Environment and Resources, 30, 441-473.

Fox, J. \& Haight, L. 2010. Subsidizing inequality: Mexican corn policy since NAFTA, Woodrow Wilson International Center for Scholars, Centro de Investigación y Docencia Económicas, University of California, Santa Cruz.

Garces-Restrepo, C., Vermillion, D. \& Muñoz, G. 2007. Irrigation management transfer: Worldwide efforts and results. FAO Water Reports. Rome, Italy: Fod and Agriculture Organization of the United Nations. 
Garrick, D. E., Schlager, E. \& Villamayor-Tomas, S. 2016. Governing an International Transboundary River: Opportunism, Safeguards, and Drought Adaptation in the Rio Grande. Publius: The Journal of Federalism, pjw002.

Godfray, H. C. J., Beddington, J. R., Crute, I. R., Haddad, L., Lawrence, D., Muir, J. F., Pretty, J., Robinson, S., Thomas, S. M. \& Toulmin, C. 2010. Food Security: The Challenge of Feeding 9 Billion People. Science, 327, 812-818.

Grothmann, T. \& Patt, A. 2005. Adaptive capacity and human cognition: The process of individual adaptation to climate change. Global Environmental Change, 15, 199-213.

Gyasi, E. A. 1994. The adaptability of African communal land tenure to economic opportunity: the example of land acquisition for oil palm farming in Ghana. Africa, 64, 391-405.

Hodgson, S. 2004. Land and Water--the Rights Interface, Food \& Agriculture Org.

Kerekes, C. B. \& Williamson, C. R. 2010. Propertyless in Peru, even with a government land title. American Journal of Economics and Sociology, 69, 1011-1033.

Kerr, J. 2007. Watershed management: lessons from common property theory. International Journal of the Commons, 1, 89-110.

Klein, R. J. T., Schipper, E. L. F. \& Dessai, S. 2005. Integrating mitigation and adaptation into climate and development policy: three research questions. Environmental Science \& Policy, 8, 579-588.

Leclère, D., Jayet, P.-A. \& De Noblet-Ducoudré, N. 2013. Farm-level Autonomous Adaptation of European Agricultural Supply to Climate Change. Ecological Economics, 87, 1-14.

Lemos, M. C., Agrawal, A., Eakin, H., Nelson, D. R., Engle, N. L. \& Johns, O. 2013. Building adaptive capacity to climate change in less developed countries. Climate science for serving society. Springer.

Liu, C., Golding, D. \& Gong, G. 2008. Farmers' coping response to the low flows in the lower Yellow River: A case study of temporal dimensions of vulnerability. Global Environmental Change, 18, 543-553.

Liverman, D. 1999. Vulnerability and Adaptation to Drought in Mexico. Nat. Resources J., 39.

Logan, B. I. \& Moseley, W. G. 2002. The political ecology of poverty alleviation in Zimbabwe's Communal Areas Management Programme for Indigenous Resources (CAMPFIRE). Geoforum, 33, 1-14.

Luers, A. L., Lobell, D. B., Sklar, L. S., Addams, C. L. \& Matson, P. A. 2003. A method for quantifying vulnerability, applied to the agricultural system of the Yaqui Valley, Mexico. Global Environmental Change, 13, 255-267.

Matson, P., Luers, A. L., Seto, K. C., Naylor, R. L. \& Ortiz-Monasterio, I. 2005. Population, land use, and environment: research directions. In: Entwisle, B. \& Stern, P. C. (eds.) Panel on New Research on Population and the Environment. Washington (DC): National Academies Press.

Mccarthy, J. J., Canziani, O., Leary, N. A. \& Dokken, D. J. (eds.) 2001. Climate Change 2001: Impacts, Adaptation and Vulnerability, Cambridge: IPCC Working Group II, Cambridge University Press.

Meinzen Dick, R. 2007. Beyond panaceas in water institutions. Proceedings of the National Academy of Sciences, 104, 15200-15205.

Meinzen Dick, R. \& Nkonya, L. K. 2007. Understanding legal pluralism in water and land rights: lessons from Africa and Asia. In: van Koppen, B., Giordano, M. \& Butterworth, J. (eds.) Community-based water law and water resource management reform in developing countries. Oxfordshire: CABI London. 
Muñoz Piña, C., De Janvry, A. \& Sadoulet, E. 2003. Recrafting rights over common property resources in Mexico. Economic Development and Cultural Change, 52, 129-158.

Murtinho, F. \& Hayes, T. M. 2011. Adaptation in Resource-Dependent Communities: A Call for Greater Methodological Clarity in Adaptation Field Research. Society \& Natural Resources, 25, 513-522.

Naylor, R. \& Falcon, W. 2012. The Yaqui Valley's Agricultural Transition to a More Open Economy. In: Matson, P. (ed.) Seeds of Sustainability: Lessons from the Birtplace of the Green Revolution in Agriculture. Washington D.C.: Island Press.

Naylor, R., Falcon, W. P. \& Puete-Gonzalez, A. 2001. Policy reforms and Mexican agriculture: views from the Yaqui valley. Economics program. International Maize and Wheat Improvement Center.

Nhemachena, C., Hassan, R. \& Chakwizira, J. 2014. Analysis of determinants of farm-level adaptation measures to climate change in Southern Africa. Journal of Development and Agricultural Economics, 6, 232-241.

Nichols, A. \& Schaffer, M. E. Clustered standard errors in Stata. United Kingdom Stata Users' Group Meetings 2007, 2007. Stata Users Group.

Onyango, L., Swallow, B., Roy, J. L. \& Meinzen-Dick, R. 2007. Coping with history and hydrology: how Kenya's settlement and land tenure patterns shape contemporary water rights and gender relations in water. In: van Koppen, B., Giordano, M. \& Butterworth, J. (eds.) Community-based water law and water resource management reform in developing countries. Oxfordshire: CABI London.

Ostrom, E. 1990. Governing The Commons, New York, Cambridge University Press.

Ostrom, E. 1998. A Behavioral Approach to the Rational Choice Theory of Collective Action: Presidential Address, American Political Science Association, 1997. The American Political Science Review, 92, 1-22.

Ostrom, E. \& Walker, J. (eds.) 2002. Trust and Reciprocity: interdisciplinary lessons from experimental research, New Yord: Russel Sage.

Palmer, A. R. \& Bennett, J. E. 2013. Degradation of communal rangelands in South Africa: towards an improved understanding to inform policy. African Journal of Range \& Forage Science, 30, 57-63.

Patt, A. \& Gwata, C. 2002. Effective seasonal climate forecast applications: examining constraints for subsistence farmers in Zimbabwe. Global Environmental Change, 12, 185195.

Phillips, J. 2003. Determinants of forecast use among communal farmers in Zimbabwe. In: O’Brien, K. \& Vogel, C. (eds.) Coping with Climate Variability: The Use of Seasonal Climate Forecasts in Southern Africa. Aldershot, UK: Ashgate.

Podsakoff, P. M. \& Organ, D. W. 1986. Self-reports in organizational research: Problems and prospects. Journal of management, 12, 531-544.

Poteete, A. R., Ostrom, E. \& Janssen, M. 2010. Working Together, Princeton, NY, Princeton University Press.

Pradhan, N. S., Sijapati, S. \& Bajracharya, S. R. 2015. Farmers' responses to climate change impact on water availability: insights from the Indrawati Basin in Nepal. International Journal of Water Resources Development, 31, 269-283.

Rabe-Hesketh, S. \& Skrondal, A. 2008. Multilevel and Longitudinal Modeling Using Stata, TX: College Station, Stata Press.

Rap, E. \& Wester, P. 2013. The practices and politics of making policy: Irrigation management transfer in Mexico. Water Alternatives, 6, 506. 
Reidsma, P., Ewert, F., Lansink, A. O. \& Leemans, R. 2010. Adaptation to climate change and climate variability in European agriculture: The importance of farm level responses. European Journal of Agronomy, 32, 91-102.

Ribot, J. 2014. Cause and response: vulnerability and climate in the Anthropocene. Journal of Peasant Studies, 41, 667-705.

Robson, J. \& Berkes, F. 2011. How Does Out-Migration Affect Community Institutions? A Study of Two Indigenous Municipalities in Oaxaca, Mexico. Human Ecology, 39, 179190.

Robson, J. P. \& Nayak, P. K. 2010. Rural out-migration and resource-dependent communities in Mexico and India. Population and Environment, 32, 263-284.

Roodman, D. 2015. BOOTTEST: Stata module to provide fast execution of the wild bootstrap with null imposed. Statistical Software Components.

Rosegrant, M. W. \& Gazmuri, R. 1995. Reforming water allocation policy through markets in tradable water rights: lessons from Chile, Mexico, and California. Cuadernos de Economía, 291-315.

Smit, B., Burton, I., Klein, R. J. \& Wandel, J. 2000. An anatomy of adaptation to climate change and variability. Climatic Change, 45, 223-251.

Smit, B., Mcnabb, D. \& Smithers, J. 1996. Agricultural adaptation to climatic variation. Climatic Change, 33, 7-29.

Smit, B. \& Wandel, J. 2006. Adaptation, adaptive capacity and vulnerability. Global Environmental Change, 16, 282-292.

Soule, M. J., Tegene, A. \& Wiebe, K. D. 2000. Land tenure and the adoption of conservation practices. American journal of agricultural economics, 82, 993-1005.

Subramanian, A., Jagannathan, N. V. \& Meinzen-Dick, R. 1997. User Organizations for Sustainable Water Services, Washington DC, The World Bank.

Tompkins, E. L. \& Adger, W. 2004. Does adaptive management of natural resources enhance resilience to climate change? Ecology and society, 9, 10.

Tucker, C. M., Eakin, H. \& Castellanos, E. J. 2010. Perceptions of risk and adaptation: Coffee producers, market shocks, and extreme weather in Central America and Mexico. Global Environmental Change, 20, 23-32.

Turner, B. L., Matson, P. A., Mccarthy, J. J., Corell, R. W., Christensen, L., Eckley, N., Hovelsrud-Broda, G. K., Kasperson, J. X., Kasperson, R. E., Luers, A., Martello, M. L., Mathiesen, S., Naylor, R., Polsky, C., Pulsipher, A., Schiller, A., Selin, H. \& Tyler, N. 2003. Illustrating the coupled human-environment system for vulnerability analysis: Three case studies. Proceedings of the National Academy of Sciences, 100.

Vásquez-León, M., West, C. T. \& Finan, T. J. 2003. A comparative assessment of climate vulnerability: agriculture and ranching on both sides of the US-Mexico border. Global Environmental Change, 13, 159-173.

Vermillion, D. 1997. Impacts of Irrigation Management Transfer: A Review of the Evidence. Colombo, Sri Lanka: International Irrigation Management Institute.

Villamayor-Tomas, S. 2014. Cooperation in common property regimes under extreme drought conditions: Empirical evidence from the use of pooled transferable quotas in Spanish irrigation systems. Ecological Economics, 107, 482-493.

Walsh, C. 2008. Building the borderlands: a transnational history of irrigated cotton along the Mexico-Texas border, Texas A\&M University Press. 
Wheeler, S., Zuo, A. \& Bjornlund, H. 2013. Farmers' climate change beliefs and adaptation strategies for a water scarce future in Australia. Global Environmental Change, 23, 537547.

Ziervogel, G. 2004. Targeting seasonal climate forecasts for integration into household level decisions: the case of smallholder farmers in Lesotho. The Geographical Journal, 170, 621. 


\section{Appendices}

Table A1. Survey items and variables

\begin{tabular}{|c|c|c|}
\hline Variable & Survey items & Operationalization \\
\hline Response effectiveness & $\begin{array}{l}\text { How did you respond to the identified } \\
\text { disturbance? Did your response accomplish its } \\
\text { objectives/apply on time/have any unattended } \\
\text { negative issue on your agricultural } \\
\text { activity/create externalities on other farmers? } \\
\text { Would it be useful to cope with the disturbance } \\
\text { in the future? Would you recommend it? }\end{array}$ & $\begin{array}{l}\text { 1=the response } \\
\text { accomplished its } \\
\text { objectives, was applied on } \\
\text { time, did not have any } \\
\text { unattended effects, did not } \\
\text { create problems to other } \\
\text { farmers, would be } \\
\text { applicable in the future, } \\
\text { and is recommendable; } \\
0=\text { the response did not } \\
\text { fulfill one or more of the } \\
\text { above criteria }\end{array}$ \\
\hline Valley & -- & $\begin{array}{l}0=\text { Yaqui valley; } \\
1=\text { Conchos valley }\end{array}$ \\
\hline Disturbance benevolence & $\begin{array}{l}\text { Out of the following list of adverse events, } \\
\text { which ones were the most problematic in the } \\
\text { last ten years? Please mark the three most } \\
\text { problematic, from } 1 \text { (most problematic) to } 3 \\
\text { (least problematic). }\end{array}$ & $\begin{array}{l}1=\text { first ranked event } \\
2=\text { second ranked event } \\
3=\text { third ranked event }\end{array}$ \\
\hline WUA Performance & $\begin{array}{l}\text { How well do farmers in this system comply } \\
\text { with water allocation/fee payment/assistance to } \\
\text { meetings? } \\
\text { Are you satisfied with the following aspects } \\
\text { related to water administration in your system? } \\
\text { (Quantity of water allocation/timing of water } \\
\text { allocation/infrastructure maintenance/conflict } \\
\text { solving) }\end{array}$ & $\begin{array}{l}1=\text { all types of rules are } \\
\text { "well" followed by farmers } \\
\text { and satisfied with all water } \\
\text { administration aspects; } \\
0=\text { any type of rule is } \\
\text { "irregularly" or "badly" } \\
\text { followed by farmers or } \\
\text { and/or not fully satisfied } \\
\text { with all water } \\
\text { administration aspects }\end{array}$ \\
\hline Communal land & -- & $\begin{array}{l}1=\text { majority of land in } \\
\text { system is communally } \\
\text { owned; } \\
0=\text { majority of land is } \\
\text { privately owned }\end{array}$ \\
\hline Information & $\begin{array}{l}\text { Which of the following information sources do } \\
\text { you rely on to get updates on agricultural } \\
\text { matters? (Radio/conversations/local } \\
\text { authorities/Distrito/Looking at other } \\
\text { farmers/public authorities/ejido } \\
\text { committee/internet/CONAGUA/modulo/unidad/ } \\
\text { NGO/family/other) }\end{array}$ & $\begin{array}{l}0=\text { rely on one source of } \\
\text { information; } 1=\text { rely on } \\
\text { more than one source of } \\
\text { information }\end{array}$ \\
\hline $\begin{array}{l}\text { Economic resources } \\
\text { (large farm) }\end{array}$ & $\begin{array}{l}\text { How many hectares of land have you usually } \\
\text { cultivated in the last decade? }\end{array}$ & $\begin{array}{l}1=\text { farmer usually cultivates } \\
\text { more than } 20 \text { hectares; }\end{array}$ \\
\hline
\end{tabular}




\begin{tabular}{|l|l|l|}
\hline & \multicolumn{1}{|c|}{} & $\begin{array}{l}0=\text { farmer usually cultivates } \\
\text { less than 20 hectares }\end{array}$ \\
\hline $\begin{array}{l}\text { Government support } \\
\text { recipient }\end{array}$ & $\begin{array}{l}\text { Have you received monetary support in the past } \\
\text { from the government or other governmental } \\
\text { agencies for aspects related to your agricultural } \\
\text { activity? }\end{array}$ & $\begin{array}{l}1=\text { yes; } \\
0=\text { no }\end{array}$ \\
\hline Dependence on irrigation & $\begin{array}{l}\text { Which part of your income corresponds to the } \\
\text { following activities (nothing, a bit, half, most of } \\
\text { it, all of it)? (irrigation farming, dryland } \\
\text { farming, cattle, employee in the } \\
\text { services/industry sector, not agricultural own } \\
\text { business) }\end{array}$ & $\begin{array}{l}\text { corresponds to irrigation } \\
\text { farming; } \\
0=\text { at least a bit of the } \\
\text { income corresponds to an } \\
\text { activity that is not } \\
\text { irrigation farming. }\end{array}$ \\
\hline Dependence on credit & $\begin{array}{l}\text { Do you usually ask for credit in order to } \\
\text { cultivate your field? }\end{array}$ & $\begin{array}{l}1=\text { yes; } \\
0=\text { no }\end{array}$ \\
\hline
\end{tabular}

Table A2. Percentage of disturbance instances addressed by different responses

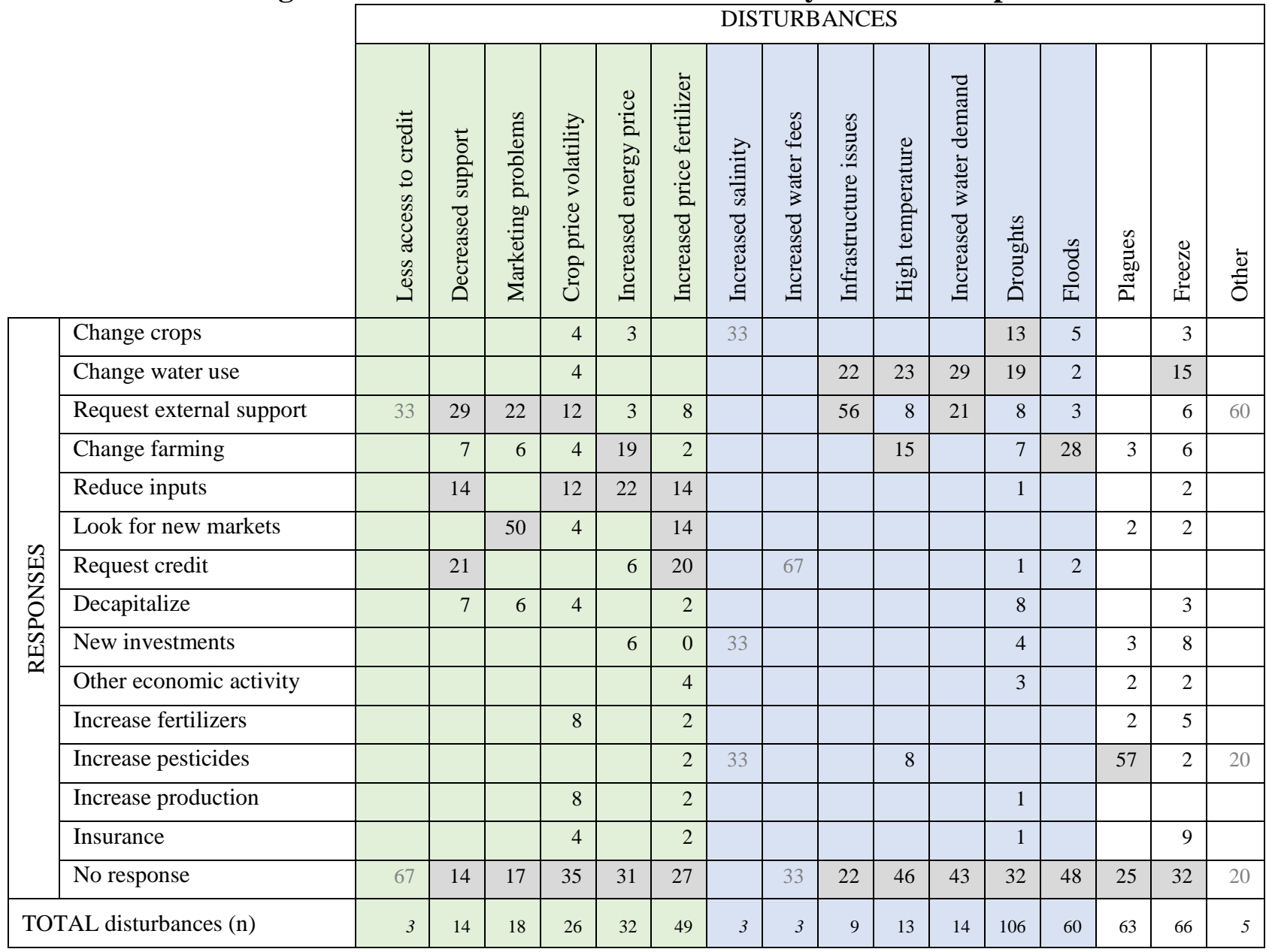

In grey: percentages that are not very meaningful given the low number of observations (see TOTAL disturbances figures in italics) 
Table A3. Collective responses carried through the WUA

\begin{tabular}{|c|c|c|}
\hline Case type & Case & Responses during drought* \\
\hline \multirow[t]{2}{*}{$\begin{array}{l}\text { Private } \\
\text { property, } \\
\text { Module }\end{array}$} & $\begin{array}{l}\text { Module 1 } \\
\text { (District 90, } \\
\text { Conchos) }\end{array}$ & $\begin{array}{l}\text { Technical } \\
-\quad \text { Improvements in irrigation canals } \\
-\quad \text { Leveling lands } \\
\text { Institutional } \\
-\quad \text { Penalties for non-payment of water dues } \\
-\quad \text { Water transfers from other modules in district } \\
\text { Political } \\
-\quad \text { Lobby CONAGUA for increase in water volume (guarantee rights) }\end{array}$ \\
\hline & $\begin{array}{l}\text { Module } K-91 \\
\text { (District } 41 \\
\text { Yaqui) }\end{array}$ & $\begin{array}{l}\text { Technical } \\
-\quad \text { Improvements in irrigation canals } \\
-\quad \text { Leveling lands } \\
-\quad \text { Water pumps to reuse water } \\
-\quad \text { Building water wells } \\
\text { Institutional } \\
-\quad \text { Restrictions in irrigation turns } \\
-\quad \text { Penalties for non-payment of water dues } \\
-\quad \text { Increasing monitoring \& enforcement of rules } \\
\text { Political } \\
-\quad \text { Fight against new inter-region water transfer project } \\
\end{array}$ \\
\hline \multirow[t]{2}{*}{$\begin{array}{l}\text { Collective } \\
\text { property, } \\
\text { Module }\end{array}$} & $\begin{array}{l}\text { Module } 3 \\
\text { (District 90, } \\
\text { Conchos) }\end{array}$ & $\begin{array}{l}\text { Technical } \\
-\quad \text { Improvements in irrigation canals }\end{array}$ \\
\hline & $\begin{array}{l}\text { Santini Module } \\
\text { (District } 41 \\
\text { Yaqui) }\end{array}$ & $\begin{array}{l}\text { Technical } \\
-\quad \text { Improvements in irrigation canals } \\
-\quad \text { Water pumps to reuse water } \\
-\quad \text { Building water wells } \\
\text { Capacity building } \\
-\quad \text { Participation in program technical advice program (RIGRAT) provided by } \\
\text { CONAGUA } \\
\text { Institutional } \\
-\quad \text { Restrictions in irrigation turns } \\
-\quad \text { Increasing monitoring and enforcement of rules } \\
\text { Political } \\
-\quad \text { Fight against new inter-region water transfer project }\end{array}$ \\
\hline $\begin{array}{l}\text { Private } \\
\text { property, } \\
\text { Units }\end{array}$ & $\begin{array}{l}\text { Pueblito } \\
\text { (Conchos) }\end{array}$ & $\begin{array}{l}\text { Technical } \\
\text { - Improvements in irrigation canals } \\
\text { Institutional } \\
-\quad \text { Penalties for non-payment of water dues } \\
-\quad \text { Increasing monitoring \& enforcement of rules }\end{array}$ \\
\hline $\begin{array}{l}\text { Collective } \\
\text { property, } \\
\text { Units }\end{array}$ & $\begin{array}{l}\text { Maclovio } \\
\text { (Conchos) }\end{array}$ & $\begin{array}{l}\text { Technical } \\
-\quad \text { Improvements in irrigation canals } \\
\text { Political } \\
\text { - } \quad \text { Lobby CONAGUA to introduce flexibility in one-season cropping }\end{array}$ \\
\hline $\begin{array}{l}\text { Collective } \\
\text { property, } \\
\text { CONAGUA } \\
\text { (outlier) } \\
\end{array}$ & $\begin{array}{l}\text { Bacum } \\
\text { Community } \\
\text { (District 18, } \\
\text { Yaqui) } \\
\end{array}$ & $\begin{array}{l}\text { Political } \\
-\quad \text { Fight against new inter-region water transfer project }\end{array}$ \\
\hline
\end{tabular}

* Excludes two government-mandated responses: Reducing water availability, done during one extreme drought in each valley (applied in all cases except in the Bacum community), and reducing annual crop cycles from two to one (applied in all cases).

** All aspects directly related to water management are handled by a private company hired by CONAGUA. 
Table A4. Different operationalizations of response effectiveness

\begin{tabular}{|l|l|l|l|l|l|l|}
\hline Variable & Operationalization & Min/Max & Mean & $p 25 / p 50$ & $S t d$ & $C V$ \\
\hline Full effectiveness & (see Table A1) & $0 / 1$ & 0.59 & $0 / 1$ & 0.49 & 0.83 \\
\hline Average effectiveness & $\begin{array}{l}\text { Average of 6 effectiveness } \\
\text { indicators }\end{array}$ & $0 / 1$ & 0.87 & $0.8 / 1$ & 0.21 & 0.24 \\
\hline Ordinal effectiveness & Sum or 6 effectiveness indicators & $0 / 6$ & 5.2 & $5 / 6$ & 1.23 & 0.24 \\
\hline $\begin{array}{l}\text { Log of ordinal } \\
\text { effectiveness }\end{array}$ & $\begin{array}{l}\text { Log of sum of 6 effectiveness } \\
\text { indicators }\end{array}$ & $0 / 1.79$ & 1.61 & $1.6 / 1.79$ & 0.34 & 0.21 \\
\hline
\end{tabular}

Note: As shown by the measures of central tendency, data is positively skewed. "Full effectiveness" results in the highest coefficient of variation.

Table A5. Descriptive statistics of WUA and farmer variables

\begin{tabular}{|l|c|c|c|c|c|}
\hline Variable & Mean & Median & Std & Min/max & $n$ \\
\hline WUA performance & 0.24 & 0 & 0.48 & $0 / 1$ & 151 \\
\hline Communal land & 0.59 & 1 & 0.49 & $0 / 1$ & 168 \\
\hline Economic resources (large farm) & 0.30 & 0 & 0.49 & $0 / 1$ & 168 \\
\hline Information & 0.48 & 1 & 0.94 & $1 / 4$ & 168 \\
\hline Government support recipient & 0.57 & 1 & 0.49 & $0 / 1$ & 168 \\
\hline Irrigation dependence & 0.49 & 0 & 0.49 & $0 / 1$ & 167 \\
\hline Dependence on credit & 0.4 & 0 & 0.49 & $0 / 1$ & 165 \\
\hline
\end{tabular}

Note 1: the number of observations reflects the number of farmers surveyed, not the number of observations included in the analysis. The sample used in the regression analysis included between 234 and 293 observations (responses to disturbances), depending on the variables included in the analysis (i.e., missing data)

\section{A6. Commentary on selection, omitted variable and self-report biases}

Our analysis was particularly vulnerable to three types of well-recognized biases in social science research (Cook and Campbell, 1979). One is selection bias. As our samples were partially preselected by leaders of the irrigation associations, there was the risk that farmers' assessments of irrigation management and response effectiveness were biased upward. Our strategy of stratifying the sample by wealth was one way to cope with that bias (see section 3.1). Additionally, we relied on a relatively large number of survey items to assess WUA performance (7) and response effectiveness (6), which expectedly contributed to further reduce the bias. Indeed, correlations between the WUA performance items and farm size (i.e., a proxy for economic resources) varied considerably depending on the item (5 not significant correlations and 2 significant correlations at $95 \%$ confidence level; minimum correlation=-0.001, and maximum correlation=0.176). The same occurred with the response effectiveness items (4 not significant correlations and 2 significant correlations at $95 \%$; minimum correlation=-0.079, and maximum correlation=0.126). 
Second, there was a potential omitted variables bias, meaning that unobserved features that were common to the population of farmers in a case or a valley were correlated to the dependent and explanatory variables. That would prevent us from generalizing across the cases. To minimize that risk we followed combined robust cluster errors and dummy variables. Specifically we used dummies to control for valley effects, and used clustered errors to control for WUA effects (Cameron and Miller, 2015, Roodman, 2015, Nichols and Schaffer, 2007) ${ }^{3}$. Errors were estimated separately via the Webb's six-point version of the wild clusters bootstrap (Cameron and Miller, 2015).

Lastly, there was a potential measurement bias, as both the WUA performance and the response effectiveness scores were based on self-reports, and thus subject to cognitive and normative preconditions (Podsakoff and Organ, 1986). We aimed to minimize the impact of those preconditions by using multiple survey items for each of the two variables. Just $50 \%$ and $25 \%$ of the farmers assessed all response effectiveness items and WUA performance items positively.

\footnotetext{
${ }^{3}$ It is recommendable to specify clustering at the highest of all nested levels at which intra-cluster correlation in errors may be a problem, but there is a tradeoff: at higher levels the number of clusters will be smaller, so the asymptotic results for the estimator are less likely to hold (Nichols and Shaffer 2007). In this study, clustering at the valley level meant using too few clusters (just two); also, we were interested in assessing the valley effect. Clustering at the WUA level meant using 7 clusters, which fell within appropriate limits if the errors are estimated via the Webb's six-point version of the wild clusters bootstrap (Cameron et al. 2015).
} 